\title{
The Larynx of the White-tailed Deer
}

\author{
Andre BISAILLON \\ Bisaillon A., 1985: The larynx of the white-tailed deer. Acta theriol., \\ 30, 6: 139-148 [With 4 Figs.] \\ This study, based on the dissection of seven specimens, describes \\ the gross anatomy of the larynx of the white-tailed deer Odocoileus \\ virginianus, Rafinesque 1832 . Results are discussed in comparisons with \\ those found in domestic ruminants. \\ [Département d'Anatomie et Physiologie animales, Faculte de \\ Médecine vétérinaire, Université de Montréal, C.P. 5000, Saint-Hyacinthe, \\ Québec, Canada J2S 7C6]
}

\section{INTRODUCTION}

The gross anatomy of the larynx in domestic mammals is relatively well documented. However, there are few studies dealing with laryngeal anatomy of non-domestic species and especially of the white-tailed deer (Odocoileus virginianus). Negus (1962), in his classical work on the comparative anatomy and physiology of the larynx, referred to many species of mammals, including some cervids, but did not describe any laryngeal structure of the white-tailed deer.

This study was undertaken to describe the larynx of the white-tailed deer and, to compare its gross structures with those of the domestic ruminants.

\section{MATERIAL AND METHODS}

The present study is based on the dissection of seven larynxes from animals of unknown age and sexes. The body weight of the specimens was not recorded. The larynxes were placed in a $10 \%$ formalin solution and, after a few days of fixation, the organs were kept in a commercial preservative solution pending further dissection.

The nomenclature follows, when applicable, the Nomina Anatomica Veterinaria (1973). The texts used for comparisons with domestic ruminants are those of Hare (1975), Barone (1976) and Nickel et al. (1979).

\section{RESULTS}

\section{Cartilages of the Larynx (Fig. 1)}

The laryngeal cartilages in Odocoileus consist of unpaired epiglottic, thyroid and cricoid cartilages in a rostrocaudal sequence and paired [139] 
arytenoid cartilages rostrodorsally. The epiglottic and the corniculate processes of the arytenoid cartilages are made of elastic cartilage, the remainder consist of hyaline cartilage.
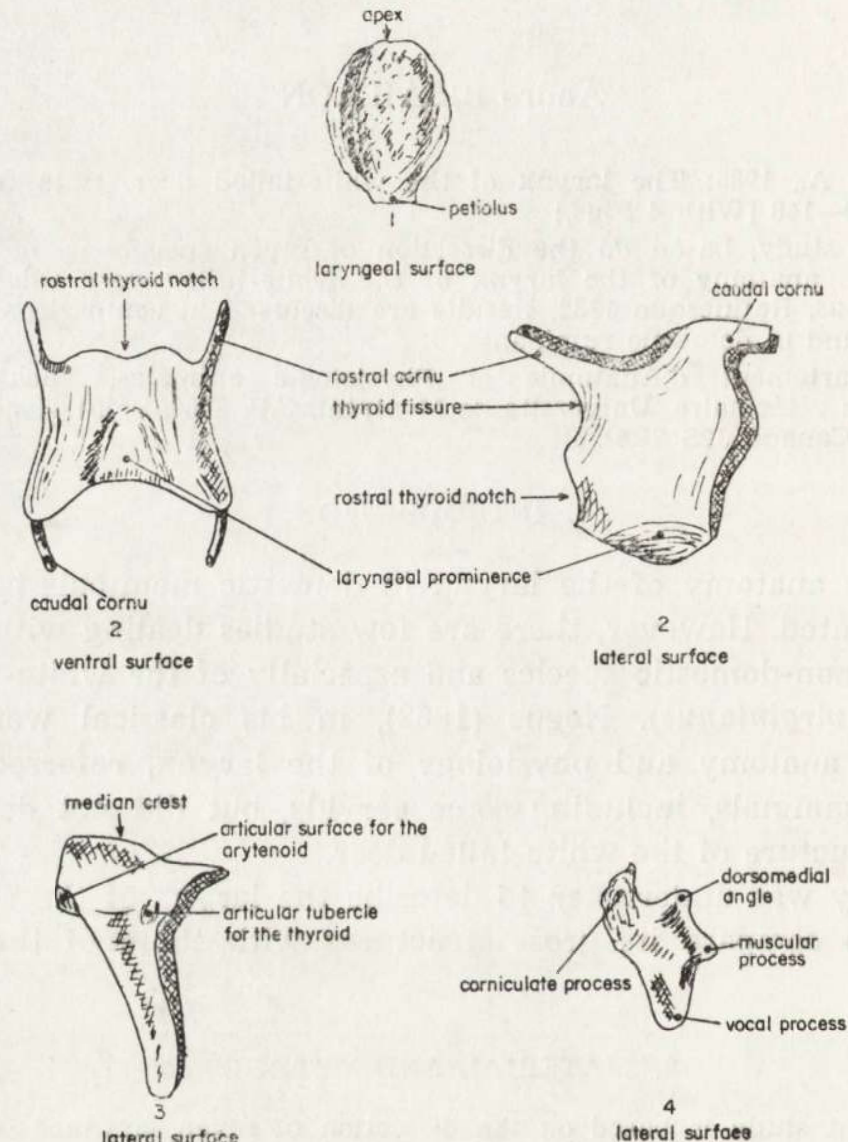

Fig. 1. Laryngeal cartilages of the white-tailed deer. 1: epiglottic, 2: thyroid, 3: cricoid, 4: arytenoid.

\subsection{Epiglottic Cartilage}

The epiglottic cartilage is short and wide. Its apex is rounded and curves ventrally. Its lateral margins are rounded and regular in outline. Its base narrows somewhat and forms a wide and very short petiolus. The lingual surface of the cartilage is concave from apex to base and convex from side to side. The laryngeal surface has the reverse conformation. Both surfaces are pitted. 


\subsection{Thyroid Cartilage}

The thyroid cartilage is shorter rostrocaudally than dorsoventrally. It is composed of two lateral laminae, which are joined ventrally forming a distinct and strong laryngeal prominence. In two specimens, the prominence was ossified. Each lamina is relatively thin and has smooth medial and lateral surfaces. The oblique line is indistinct. The rostral cornu is thin, long and, straight. It is directed rostrodorsally. Its medial face shows on its tip a rounded, small and, flat hyoid articular surface. The rostral cornu forms with the rostral border of the lamina a relatively shallow and wide thyroid fissure. In the fresh state the fissure is converted into a small thyroid foramen by connective tissue. In one specimen the right and left thyroid foramina are completely surrounded by cartilaginous tissue, while in an other specimen this is the case only on the left side. The caudal cornu is shorter but thicker than its rostral homologue. It is directed caudally and medially. A small concave cricoid articular surface is placed on the medial face of its caudal end. The caudal cornu forms with the caudal border of the lamina a deep and wide notch. The middle third of the caudal border is strongly convex and thicker than the remaining part of the border. Ventrally the caudal border of the cartilage is slightly concave and the caudal thyroid notch is indistinct. Ventrally also, the rostral border of the cartilage shows a well defined, but shallow rostral thyroid notch.

\subsection{Cricoid Cartilage}

The cricoid cartilage is shaped like a signet ring and consists of a relatively long lamina dorsally and a thick arch laterally and ventrally. The lamina is an irregular pentagonal plate which tapers caudally. Its dorsal surface is flat and divided into two halves by a low median crest, which fades out caudally; its ventral or inner surface is concave transversally. The rostral border of the lamina is much thicker than the caudal border. It presents on either side a small, oval, convex facet for articulation with the arytenoid cartilage. At the junction of the lamina and the arch and close to the caudal border, there is one either side of the lateral face, a small articular rough tubercle for the caudal cornu of the thyroid cartilage. The arch of the cricoid cartilage slopes ventrocaudally. The arch narrows somewhat ventrally and forms a faint, median, rostral concavity. The rostral border of the arch is thicker than the caudal one. Its corsal two thirds show an elongated ridge for muscular attachment. 


\subsection{Arytenoid Cartilage}

Each arytenoid cartilage is irregularly pyramidal with a rostral apex and a caudal base. The base consists of a distinct and blunt dorsomedial angle, a strong long, and prominent dorsolateral muscular process and a thick short, wide, and rounded vocal process ventrally. The lateral, dorsal and, medial surfaces of the cartilage are slightly concave. An oval and concave articular facet for the lamina of the cricoid cartilage is present on the medial surface of the muscular process. The apex of each arytenoid cartilage bears a horn-shaped corniculate process. This process is thin and directed dorsally and caudally. Both lateral and medial surfaces of the corniculate process as well as the rostral and caudal edges are uneven and pitted.

\subsection{Muscles of the Larynx (Figs. 2, 3)}

The intrinsic laryngeal muscles consist of the paired cricothyroideus, cricoarytenoideus lateralis, cricoarytenoideus dorsalis, thyroarytenoideus, and the unpaired arytenoideus transversus.

$M$. cricothyroideus. This thick, fan-shaped muscle lies on the lateral surface of the larynx between the cricoid arch and the thyroid lamina. From its origin on the lateral surface and caudal border of the arch of the cricoid cartilage, the muscle runs rostrally and dorsally to insert into the medial surface and caudal border of the lamina and into the ventrolateral and ventromedial surfaces of the caudal cornu of the thyroid cartilage. Ventrally, the muscular fibers attach to the lateral surface of the lamina.

M. cricoarytenoideus lateralis. This small muscle lies medial to the lamina of the thyroid cartilage. It arises from the dorsal two thirds of the rostral border and adjacent lateral and medial surfaces of the arch of the cricoid cartilage. The fibers pass dorsally and slightly rostrally to insert on the ventrolateral aspect of the muscular process of the arytenoid cartilage.

$M$. cricoarytenoideus dorsalis. This flat muscle lies on the dorsal surface of the cricoid cartilage. It originates from the entire dorsal surface and median crest of the lamina of the cricoid cartilage. The fibers run rostrally and laterally and converge to attach on the dorsolateral aspect of the muscular process of the arytenoid cartilage.

$M$. thyroarytenoideus. This wide muscle lies medial to the lamina of the thyroid cartilage. The $m$. thyroarytenoideus is partly divided into a narrow rostral part representing the $m$. ventricularis and a wide fanshaped, caudal part or $m$. vocalis. From the vocal ligament and caudal to it, the $m$. vocalis is thicker than its remainder part, but it forms a 
uniform triangular mass. The vocal muscle arises along the entire length of the internal ventral midline of the thyroid cartilage, from the basal part of the epiglottis, and from the thyroepiglottic ligament. From its ventral origin, caudal fibers passing dorsally and rostral fibers passing caudodorsally, converge and insert on the lateral surface of the vocal process and the adjacent surface of the arytenoid cartilage. The $m$. ven-

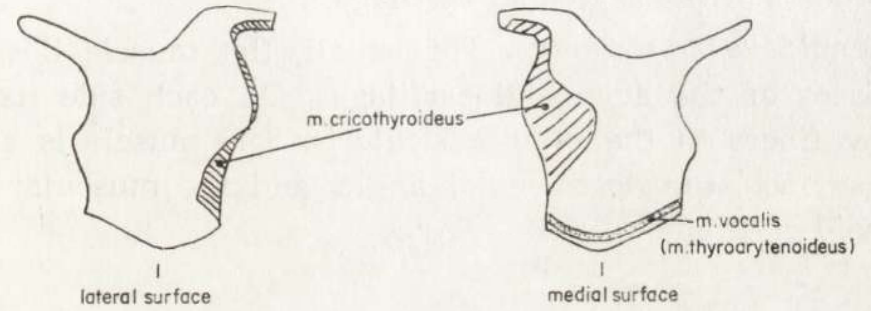

origin

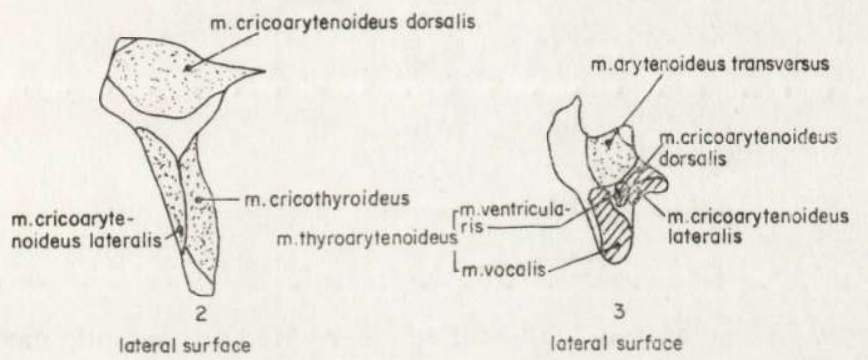

Fig. 2. Attachments of the laryngeal muscles of the white-tailed deer, 1: thyroid 2: cricoid, 3: arytenoid.

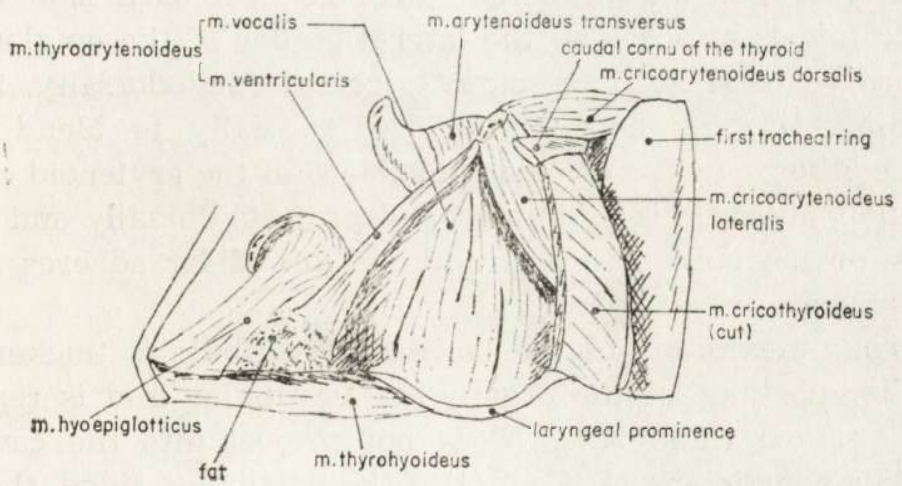

Fig. 3. Laryngeal muscles of the white-tailed deer (left thyroid lamina removed). 
tricularis represents the superficial, rostral division of the $m$. thyroarytenoideus. The deep face of this narrow and thin muscular strip blends with the vocal portion of the $m$. thyroarytenoideus. At its dorsal attachment, the $m$. ventricularis receives some connecting fibers from the $m$. arytenoideus transversus. From its ventral attachment on the base of the epiglottis in the area of the fat cushion, the ventricular muscle passes caudodorsally to attach superficially on the rostral aspect of the muscular process of the arytenoid cartilage.

M. arytenoideus transversus. This small, flat muscle lies across the dorsal surfaces of the arytenoid cartilages. On each side its deep face sends a few fibers to the $m$. ventricularis. The muscle is attached on the dorsal surface, the dorsomedial angle, and the muscular process of each arytenoid cartilage.

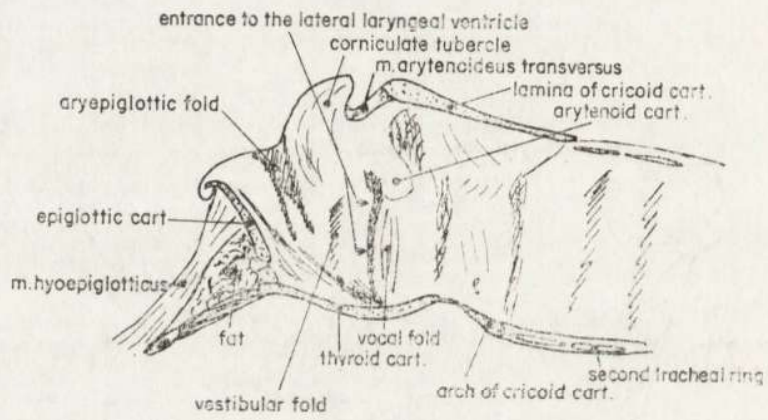

Fig. 4. Laryngeal cavity of the white-tailed deer. Median section, medial aspect.

\subsection{Cavity of the Larynx (Fig. 4)}

The entrance to the laryngeal cavity is transversally wide and is oriented obliquely in a rostrodorsal direction. On each side the thick aryepiglottic fold is attached to the lateral border of the epiglottis along which it forms a shallow depression. It passes caudodorsally, lateral to the corniculate process, and then curves medially to blend with its fellow of the other side over the dorsal surface of the arytenoid cartilages. The corniculate tubercle is prominent and projects dorsally and caudally. At the base of the epiglottis, a strong cushion of fat adheres firmly to its lingual surface.

The mucous membrane of the laryngeal vestibule is thicker than in the remainder portions of the organ. The vestibular fold is represented by a faint vertical ridge which does not project into the cavity. The vestibular ligament is absent. Caudal to the vestibular ridge, the mucosa passes caudally for a short distance between the vocal portion of the 
thyroarytenoid muscle laterally and the vocal fold medially. This shallow evagination forms a small lateral laryngeal ventricle.

The rima glottidis is relatively narrow. Its intramembranous part which is bounded by the paired vocal folds has about the same dorsoventral height than its intercartilaginous part which lies between the medial surfaces of the two arytenoid cartilages. From their ventral attachment on the caudal part of the internal ventral midline of the thyroid cartilage, the vocal folds diverge somewhat laterally to attach dorsally on the corresponding arytenoid cartilage. Each vocal fold is thick and rostrocaudally wide. It forms a vertical ridge which runs at an angle of 85 to 90 degrees to the long axis of the larynx. Because of the presence of the shallow lateral ventricle, the vocal fold projects freely into the laryngeal lumen and is covered by the mucosa rostrally, laterally and, medially. Each fold contains a strong vocal ligament in its rostral convex border. This ligament lies in the $m$. vocaits and attaches dorsally to the tip of the vocal process of the arytenoid cartilage.

The infraglottic cavity is transversally wider dorsally than ventrally. Its dorsoventral height diminishes slightly toward the trachea. Because of the prominence of the paired arytenoid cartilages, there is, on either side, a shallow depression in the rostrodorsal angle of the caudal laryngeal compartment.

\section{DISCUSSION}

The cartilaginous skeleton of the larynx in Odocoileus is composed of the same elements as in domestic ruminants. The cuneiform, interarytenoid and, sesamoid cartilages are absent. Among the domestic mammals, these cartilages are inconstant.

In the deer and ox, the epiglottic cartilage is short and wide with a rounded apex. The apex is pointed in small ruminants. Like in domestic ruminants, the base of the cartilage ends by a short and wide petiolus.

In Odocoileus, the thyroid cartilage is rostrocaudally shorter than high. In large domestic animals, the thyroid laminae are longer than high. Hare (1975) mentioned that the laminae are relatively shorter and higher in the sheep and goat than in the ox. Barone (1976) stated that in the small ruminants, the thyroid cartilage is more developped dorsoventrally than rostrocaudally. Saber (1983) wrote that in the sheep, the laminae are longer than high.

The oblique line on the lateral face of each thyroid lamina is indistinct in Odocoileus and prominent in large domestic mammals. In the deer, the rostral cornu of the thyroid cartilage is long, thin, and straight, while the caudal cornu is relatively short and thick. In cattle and small 
ruminants, the rostral cornu is short and straight and the caudal cornu curves ventrally. The rostral thyroid notch is shallow in the deer and very shallow in the ruminants. Saber (1983) indicated that in the sheep, the rostral thyroid notch is deep, while the caudal one is very shallow.

In Odocoileus, the laryngeal prominence is strongly developed and forms almost all the ventral surface of the thyroid cartilage. In the domestic ruminants, the prominence is slight. In this study, two specimens showed an ossified laryngeal prominence. Barone (1976) mentioned that in the ox, the laryngeal prominence is thick and is invaded by ossification in the early age. Recently, Glass and Pesch (1983) indicated that in the roe deer (Capreolus capreolus), the thyroid cartilage ossifies in two) preferential directions. They showed that in this species, ossification of the larynx begins with the thyroid cartilage during the first year of life. They gave as the cause of ossification of the laryngeal cartilages, their deformation by the muscles of the larynx. In the dog, Piérard (1968) showed that ossification or calcification of the laryngeal cartilages is related to the age and sex of the specimens.

The overall shape of the cricoid cartilage of the deer approximates that of the sheep and goat. The lamina with its low median crest is irregularly pentagonal in the deer but, quadrilateral in ruminants. The arch of the cricoid cartilage in Odocoileus, like in small ruminants is directed ventrocaudally. In the deer, like in ruminants, the small, articular area for the caudal cornu of the thyroid cartilage is rough for a syndesmotic attachment of the two cartilages.

The muscular process of the arytenoid cartilage is strong, long and prominent in the deer, while it is short and thick in the ox. The vocal process is short and wide in the deer; it is long and narrow in all the domestic ruminants. The corniculate process is shaped like a horn in the deer and in large domestic species. It curves caudodorsally in all animals.

The laryngeal muscles of the white-tailed deer basically resemble those of the domestic mammals. In Odocoileus, the $m$. thyroarytenoideus is partly divided into a superficial, rostral portion or $m$. ventricularis, and a broad, caudal portion or $m$. vocalis. Nickel et al. (1979), Getty (1975), and Barone (1976) mentioned that the $m$. thyroarytenoideus of the ruminants forms a uniform plate which is not divided into ventricularis, and vocalis. Getty (1975) added that the dorsal part of the thyroarytenoid muscle has a twisted appearance because its rostral fibers lie superfical to its caudal fibers. On the other hand, Barone (1976) indicated in his drawings of the laryngeal muscles of the ox, that the $m$. thyroarytenoideus is divided into a rostral $m$. ventricularis and a caudal $m$. vocalis. According to Piérard (1963), the $m$. vocalis as described 
in the veterinary literature corresponds to the $m$, thyroarytenoideus of the human anatomy and it is not homologous with the vocal muscle of man, because in this species the vocal muscle is represented by medial fibres of the thyroarytenoid muscle which lie parallel with the vocal ligament (Goss, 1973). Piérard (1963) also suggested that the term $m$. ventricularis be dropped as an anatomical term, at least for the dog, because this muscle bundle is part of the transverse arytenoid muscle and is not homologous with the individual rostral portion of the $m$. thyroarytenoideus, sometimes recognized in the human (Goss, 1973).

In the white-tailed deer, like in ruminants, the aryepiglottic fold is strong and blends with its counter part over the dorsal surface of the arytenoid cartilages. In Odocoileus, the vestibular fold is faint while it is absent in ruminants. The lateral laryngeal ventricle of the deer forms a shallow evagination between the $m$. vocalis and the wide vocal fold. Ruminants lack lateral laryngeal ventricle and instead have very shallow depressions on each lateral wall of the larynx. Negus (1962) showed that the reindeer (Rangifer tarandus) also has a very shallow fossa in place of the lateral laryngeal ventricle and a dilatable median subhyoid air sac.

In Odocoileus, unlike in ruminants, the vocal fold projects freely into the cavity of the larynx and, the mucous membrane covers it both medially and laterally. Like in the ox, the vocal fold of the deer is placed at nearly right angle to the long axis of the organ.

Acknowledgements: The author is grateful to Richard Bourassa for his technical assistance, to Pierre Demers for lettering the illustrations and to Sylvie Ponton for typing the manuscript and, to doctors Jean Piérard and Laszlo DeRoth for critical revision of the manuscript.

\section{REFERENCES}

1. Barone R., 1976: Anatomie comparée des mammifères domestiques. Tome troisième, Splanchnologie, foetus et ses annexes. Fascicule premier - Appareil digestif - Appareil respiratoire. Ecole nationale véterinaire, Lyon.

2. Getty R., 1975: Sisson and Grossman's The anatomy of the domestic animals. W. B. Saunders Company, 1. Philadelphia, London, Toronto.

3. Glass W., von \& Pesch H.-J., 1983: Zum Ossifikationsprinzip des Kehlkopfskelets von Mensch und Säugetieren. Acta Anat., 116: 158-167.

4. Goss C. M., 1973: Gray's anatomy of the human body. 29th Am. ed., Lea and Febiger.

5. Hare W. C. D., 1975: Ruminant respiratory system. Porcine respiratory system. [In: Getty R., Sisson and Grossman's The anatomy of the domestic animals. Vol. 1, 2, 5th ed.]. W. B. Saunders Company, Philadelphia, London, Toronto.

6. Negus V. E., 1962: The comparative anatomy and physiology of the larynx. Reprinted ed., Hafner Publishing Company, New York.

7. Nickel R., Schummer A., Seiferle E. \& Sack W. O., 1979: The viscera of the 
domestic mammals. 2nd revised ed., Verlag Paul Parey, 1-Berlin und Hamburg.

8. Nomina Anatomica Veterinaria, 1973: International Committee on Veterinary Anatomical Nomenclature, 2nd ed., World Association of Veterinary Anatomists, Vienna.

9. Piérard J., 1983: Comparative anatomy of the Carnivore larynx (with special reference to the cartilages and muscles of the larynx in the dog). M. S. thesis, Cornell University.

10. Piérard J., 1968: La calcification des cartilages laryngés du chien. Economie et médecine animals, 9: 46-51.

11. Saber A. S., 1983: The cartilages of the larynx of the one humped camel (Camelus dromedarius) and sheep (Ovis aries). Zbl. Vet. Med. C., Anat. Histol. Embryol., 12: 77-84.

Accepted, October 15, 1984

André BISAILLON

\section{KRTAŃ U JELENIA WIRGINIJSKIEGO}

\section{Streszczenie}

Opisano budowę krtani Odocoileus virginianus Rafinesque, 1832, sekcjonując 7 osobników o nieznanym wieku i plci. Otrzymane dane porównano z podobnymi uzyskanymi u domowych przeżuwaczy. Krtań jeleni zbudowana jest $z$ takich samych chrząstkowych elementów jak u przeżuwaczy, mianowicie: nagłośni, chrząstki tarczycowej, chrząstki pierścieniowatej oraz chrząstki nalewkowej (Ryc. 1). Brakuje natomiast chrząstek: klinowej, międzynalewkowej i trzeszczkowej. Mięśnie krtaniowe O. virginianus, mogą byč zasadniczo porównywane z podobnymi mięśniami u gatunków udomowionych (Ryc. 2, 3). W przeciwieństwie do domowych przeżuwaczy, mięsień tarczycowo-nalewkowy u jeleni jest silniej rozbudowany i tworzy powierzchniową część rostralną i szeroką kaudalną U O. virginianus fald głosowy wnika w jamę krtaniową i boczne komory krtaniowe (Ryc. 4). U przeżuwaczy fałd głosowy przypomina masywne wyniesienia a zamiast komór są bardzo płytkie zagłębienia. 